\title{
The Analysis of North Korea's Behavior in Six Party Talks (2003-2010)
}

\author{
Puti Parameswari ${ }^{1}$ \\ \{puti.parameswari@budiluhur.ac.id ${ }^{1}$ \} \\ Program Studi Ilmu Hubungan Internasional, Fakultas Ilmu Sosial dan Ilmu Politik, \\ Universitas Budi Luhur, Jl. Ciledug Raya, Jakarta, Indonesia
}

\begin{abstract}
The clash between North Korea and South Korea has started since 1950. The conflict between ideological backgrounds and the border issues among the two countries has not been over and still continues today. The development of these conflicts indicates that there has been an ongoing increase in weaponry by both countries. Nevertheless, the peace effort still being pursued and one of them is the Six Party Talks which is initiated by China. This study analyze North Korea's behavior during Six Party Talks. Moreover, this study highlight the dynamic relations between North Korea and South Korea, particularly in the Six Party Talks as peace effort.
\end{abstract}

Keywords: Security dilemma, conflict, North Korea, South Korea, Six party talks.

\section{Introduction}

Occupation in the post-World War II era left a scar that never recovered for the territory of the Korean peninsula. The Korean peninsula is now divided into two countries, namely North Korea and South Korea. The separation of these two regions begins with foreign occupation intervention, namely the United States and the Soviet Union. The United States occupied the southern area of the peninsula, while the Soviet Union occupied the northern region of the Korean peninsula.The decision of division was arranged by the two big statethe United States and the Soviet Union-in1945, without the Korean consent. At that time no expert advisor was involved in the decision. Korea peninsula then "temporarily" divided into two occupational zones, while the Cold War took place and deepened.

The two occupational zones make Korea divided into two different regimes.The northern region of Korea was finally thick with communist ideology which is an ideology that carried by the Soviet Union. While the south of Korea is more colored by liberalism, which is the basis of the United States. The difference of ideology, i.e. communist and liberalist, is what underlies the splitting of the Korean peninsula into two regions [1]. This ideological distinction is also the basis of the background of the conflict between North and South Korea since 1950.

Peace and negotiation efforts are underway to address the peaceful condition for Korean peninsula. One such peace effort is the Six Party Talks. Six Party Talks agenda was conceived as a serious form of conflict handling on the Korean peninsula, highlighting one of the key issues of the North Korean nuclear development project which is considered quite disturbing. In other words, Six Party Talks was conducted as a multilateral platform to attain 
denuclearization of Korean peninsula [2]. North Korea has agreed to join the Six Party Talks, but the journey of peace efforts has not been smooth and started to break in 2012.

Six Party Talks orDiscussion of Six Nations is one of peace efforts current initiated by China. Six Party Talks agreement was happened on August 27th, 2003 and involved six countries, namely Russia, China, USA, Japan, North Korea and South Korea. Six Party Talks was conducted in Beijing, China. The peace efforts made in order to pave the way of peace for the conflict in the Korean peninsula. Purpose of establishing the Six Party Talks is to create a safe situation and stabilitybetween North Korea and South Korea [3].

In addition, the Six Party Talks are also established in order to facilitate the communication of other countries with the North Korean side, which is known as a country that rarely have diplomatic relations with the other state. Thus, the main issues discussed at the Six Party Talks is the matter of nuclear weapons development by North Korea. The Six Party Talks is not just reconciliation of the Korean peninsula, but also the development efforts of North Korea's communication and diplomacy over the controvercy of nuclear proliferation, which sufficient to make many countries in the world uncomfortable.

\section{Methods}

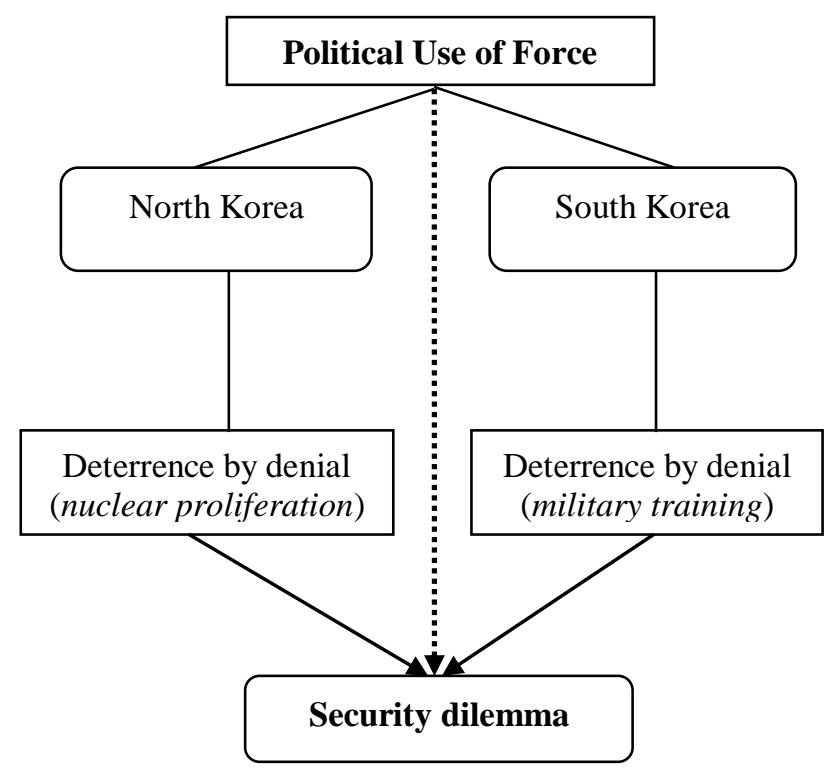

Fig. 1. Operasionalization of Theory.

The security dilemma (security defensive offensive dilemma) and political forces (political uses of force) will be the underlying theory of this study.The diagram above explains how the theory is used to analyze the behavior of North Korea in this paper.

According to Jervis, the security dilemma is one of the problems that occur and exist in the world of international politics. The dilemma of security (security dilemma) is widely translated as a state where a country improves the security of its country and reduces security for other countries. Thus, if there is a country that increases its security then the country will 
not threaten other countries withcaution.Two important variables appear. First, whether defensive strategies can be distinguished from offensive strategies-whether in terms of more military weapons, or more political policies. Second, which is more advantageous, defensive strategy or offensive strategy [4].

Art divides the political uses of force into four functional strategies: defense, deterrence, compellence, and swaggering. The defensive use of force is the spreading of the military power of a country so that it can do two things, namely to ward off attacks and minimize damage caused by the attack. The deterrent use of force is an attempt to make military force prevent others / opponents from committing an attack or any action that endangers the state. The compellent use of force is an attempt to make a country's military power able to change the behavior of others. While swaggering use of force is an outside effort other than defense, deterrence and compellent. Swaggering is one of the strategic functions of use of force that is difficult to identify.

The main aspect of deterrence is threat. Threats are made as a preventive measure for other parties from doing actions that endanger the state. Deterrence can be done in two ways, namely with prevention and punishment. The deterrence by denial (prevention) is done by opening the military power to other parties. Prevention is done by showing the power possessed by the state, in order to prevent the state or other parties to attack. The second way is with punishment, deterrence by punishment, threats that are accompanied by the threat of punishment that will give fatal consequences for others. Both ways are essentially threats, to prevent others from attacking or endangering a country [5].

\section{Research And Discussion}

Six Party Talks which is a forum in deploying peace on the Korean peninsula, as well as container diplomatic relations and communication with North Korea on developing nuclear weapons have turned out to be only lasted from 2003 until 2012. The efforts to establish communication and diplomacy with North Korea's state was not as easy as expected. During participated in the Six Party Talks, North Korea displays behaviors that are still difficult to understand and accessible by other countries. The following will explain the development of the Six Party Talks as well as the behavior of North Koreaas a state from its inception until North Korea declared out of the Six Party Talks.

\subsection{The Dynamics of North Korea's Ties with Other State of The Six Party Talks}

Starting in 2001, in which North Korea says the threat to the Bush administration. North Korea threatened to compromise the Agreed Framework between North Korea with the United States, if the Bush administration did not continue the policy of previous governments that the Clinton administration. In addition, North Korea also argues that the United States is not sincere to implement the Agreed Framework was agreed upon, and even continued to delay its implementation.

United States respond to the threat of North Korea by offering a serious dialogue between the two countries. Nonetheless, Bush expressed concern about the deal that will be woven together North Korea. Eventually in June 2001, the Bush administration envoy met North Korea's envoy in Pyongyang. This meeting resulted United States agreement to proceed talks with North Korea a review during three months. 
A year later, Bush declared in a speech that North Korea as the axis of evil in the world for developing nuclear weapons. However, negotiations and cooperation between North Korea and the United States is still ongoing. This is an evident from the activity of the talks between the two countries continuing from April to October 2002. In the same month the United States claims that North Korea admitted their nuclear weapons development is being carried out, although this is still marked by conflicts of interpretation. In October 2002, North Korea was allegedly developed the Highly Enriched Uranium program (HPU) [6].

Afterwards in November 2002, Bush said it would halt shipments of fuel oil (heavy oil)to North Korea if the country does not want to stop the pace of weapons programs [7]. North Korea was responding to Bush by threatening, that North Korea would reactivate the nuclear advancement program as a consequence of termination oil shipments by the United States, as well as expel US envoy in North Korea. Essentially, United States and North Korea have different aims. North Korea was anxious with regime viability, on the other side United States search for denuclearization [8].

In 2003, North Korea declared out of the Treaty on theNon-Proliferation of Nuclear Weapon (NPT). February 5, 2003, North Korea declared the re-activation of the Yongbyon nuclear reactor. Sometime after the declaration of North Korea, South Korea along with the United States announced it would conduct a joint military exercise in March. North Korea's response to military exercises by conducting missile launch in February and March. In April, North Korea stated its aim to establish multilateral negotiations. From here formed three countries meeting between North Korea, China and the United States. China was quite active back then as mediator up to five round of Six Party Talks from August 2003 to November 2005 [9]. In this year also formed the very first round of the Six Party Talks. This occasion was organized in Beijing, with the participation of Foreign Minister Li Zhaoxing from China [10]. No binding agreement is formed, but all parties agreed to resume the multilateral talks. Even though no binding agreement is formed, first round of the Six Party Talks manage to established institutionalized structure of dialogue dealing with the nuclear issue [11].

In 2004, US nuclear expert come to North Korea to examine the advancement of nuclear weapons, but did not find enough evidence to support North Korea's possession of nuclear weapons. The second round of the Six Party Talks took place in February 2004, members of the talks agreed to coordinate steps in handling the North Korean nuclear issue, despite not yet seen as strong commitment. The third round of meetings took place in June of the same year, all members of the Six Party Talks agreed with the efforts of real denuclearization in the Korean peninsula [7].

The decision shocked out of North Korea in early 2005. North Korea said it would redevelop nuclear weapons and suspend any form of talks until an undetermined time. South Korea claims that North Korea close down the reactor to extract nuclear weapons. In May, North Korea to participate in missile tests. Pressuresamong North Korea and South Korea was followed by the failure of the fourth round of the Six Party Talks. The fourth round was again held in September 2005 and all members of the Six Party Talkssettled to sign a "Statement of Principles", in Pyongyang. The statement agreed to stop entire nuclear programs, return to the Treaty on the Non-Proliferation of Nuclear Weapons (NPT) and welcome the United States government envoy on North Korea. Constraints re-occur, because North Korea and theUnited States are still suspicious of each other and do not trust each other.

Although the Statement of Principles was signed, the deal Six Party Talks delayed for approximately one year. This is motivated by the problems in the financial sanctions in the agreement between North Korea and the United States. The United States also freeze the assets of the Macau-based Banco Delta Asia, the United States accused the bank in money 
laundering for the nuclear program. As a result, North Korea again rejected the deal and any talks, as well as re-developing nuclear weapon. North Korea also see the United States again not enforce the Agreed Framework.

The behavior of North Korea, which shows the reaction of a failed negotiation seen in 2006. North Korea's test-launch of seven missiles and including long-range missiles. In addition, North Korea also today announced plans testing nuclear devices. In October 2006, North Korea actually did its first nuclear experiment. The results of these trials showed a weapon test results are still not meet the target of North Korea. As reaction, the United Nations Security Council passed Resolution 1718 to put in place sanctions for North Korea's nuclear test. Beijing's efforts behind the scenes negotiations proved fruitless. North Korea back to the Six Party Talks in November 2006. All members of the Six Party Talks agreed to reaffirm the Joint Statement adopted in September 2005.

In February 2007, North Korea agreed Action Plan is based on the Statement of Principle in 2005. Based the deal, North Korea agreed to close down the nuclear development facilities at Yongbyon within 60 days. In return, North Korea will gain remuneration of 50,000 tons of fuel. A distinctive bilateral dialogue with the US and Japan also will be done.

Later,the fuel aid weighing 950,000 tons will also be given after North Korea's nuclear ammunition program shut down thoroughly. In March 2007, North Korean assets in Banco Delta Asia was detached, and the International Atomic Energy Agency (IAEA) confirmed the closing of North Korea's nuclear facilities in Yongbyon. Then in October, the Six Party Talks was held back and all parties agreed to the formulation of Second Phase Action Plan which calls for North Korea to immobilize nuclear facilities in Yongbyon and to hand over the declaration of the entire nuclear program on December 31, 2007.

In 2008, North Korea handed documents containing everything about his nuclear program and a month later they released a declaration of nuclearprograms for all members of the Six PartyTalks.North Korea criticized the United States that they had a uranium enhancement program and documents submitted are still not detail. Meanwhile, the disablement of the Yongbyon reportedly almost completed and North Korea destroyed the refrigerant tower of Yongbyon experimental reactor as a commitment to them. Verification was performed and the United States pull out North Korea from the list of countries supporting terrorism.

On April 5th, 2009 North Korea attempted to place a satellite with the launch of two missiles. The first missiles fell in the waters of the Sea of Japan, while the second missile crashed in the Pacific Ocean region. North Korea's missile-launch to get criticism from the international community and was a violation of UN resolutions in 1695 and 1718 . The UN Security Council insisted abuse of the UN resolution in 1718 conducted by North Korea. The statement demanded North Korea not to continue with the missile launch attempt. In addition, a committee for the adjustment of sanctions is also formed.

North Korea responded to UN Security Council action to declare out of the Six Party Talks and expressed his intention to restore the nuclear weapons improvement program in Yongbyon. One of the media in North Korea says North Korea threatened to hold a nuclear test and missile launch back if the United Nations Security Council did not draw condemnation and apologized to North Korea. May 2009, North Korea arranged a nuclear test, and once again the international community along with the United Nations Security Council condemned the action.

The United Nations Security Council approved resolution 1874, and impose economic sanctions against North Korea. In addition, the resolution also called on North Korea to come back into the NPT and to rejoin the Six Party Talks. In September, North Korea declared its willingness to establish bilateral negotiations with the United States. After the visit of Prime 
Minister of China in October, North Korea expressed its eagerness to rejoin the Six Party Talks. Meanwhile, news from South Korea's Yonhap reported North Korea has almost completed the restoration of its main nuclear facility in Yongbyon.

In January 2010, North Korea announced the establishment of a peace covenant with the United States is a prerequisite for the return of North Korea in the Six Party Talks. Then in March 2010, the South Korean warship sank due Choenan's physical contact with a torpedo. These events yield in thedeaths of 46 South Korean soldiers. South Korea then blamed North Korea of deliberately launching torpedoes. North Korea has denied and insisted it was not involved in the incident. South Korea finally declared not willing to continue the Six Party Talks before the Choenan's incident completely resolved.

Prime Minister of Russia back to collect the Six Party Talks after North Korea said it would not eliminate its nuclear program and also would like to cooperate with other nations in a nuclear development project. Again, the Chinese side to convince North Korea to rejoin the Six Party Talks. Meanwhile South Korean military action in the border region is still ongoing. This certainly makes the tension between North Korea and South Korea are increasingly becoming the time. In November 2010, China again called Six Party Talks gathered to deal with these tensions. However, three members namely South Korea, the United States and Japan feel sixparty talks cannot be started because time is less precise and demanding North Korea disarmament before the talks resumed.

In the same month, North Korea revealed a secret uranium developmentprogram at Yongbyon. North Korea argues that the program is carried out for a light water reactor being built in the same complex. Even so, the United States and South Korea to doubt the purpose of the development of uranium enrichment by North Korea it. North Korea expressed no objections when IAEA envoys to visit and inspect the uranium enrichment program. Then, the President of South Korea expressed willingness to reopen diplomatic communications and support for the revival of the Six Party Talks in an effort to resolve the tensions of the Korean peninsula.

In 2011, South Korea and the United States re-start the program of joint military exercises. This is a defensive effort that made South Korea in the tense Korean peninsula. However, North Korea joint military exercises are seeing is the aggressive efforts of South Korea and the United States. In March 2011, South Korea rejected an offer to return to the Six Party Talks. South Korea demands North Korea to take action disarmament real and not limited to the agreement only.

In July, the negotiators of North Korea and South Korea meet again in the ASEAN Regional Forum and convey its urge to resume the Six Party Talks; the United States, Japan and Korea South back in agreement and issued a trilateral agreement, that peace efforts would be resumed if North Korea really wants to change his behavior and work well together in the peace efforts. North Korea is negotiating with the Russian side reveal inclination to resume the Six Party Talks. However, the United States and South Korea are still skeptical of the North Korean statement.

In 2012, North Korea agreed to stop all testing of nuclear, missile launches and uranium enrichment at Yongbyon. North Korea was also willing to accept IAEA envoy to watch the moratorium on uranium development. In return, the United States agreed to ship food aid as much as 240,000 metric tons to North Korea. This agreement is known as Leap Day Agreement.

Then, in April 2012, North Korea launched threeKwangmyongsong's satellites at the 100th anniversary of the death of North Korean leader Kim Il Sung. United States and South Korea saw the launch is a missile test effort was again executed by North Korea. United States 
has halted shipments of food aid to North Korea. In May, the UN Security Council issued a collective agreement that urges North Korea to meet its commitment to the Six Party Talks and stop all nuclear activities and weapons. North Korea also took the step of self-defense, and promised to resume its nuclear program [7]. After that, negotiations Six Party Talks is not yet see the meeting point until the end of year.

\subsection{The Analysis of North Korea's Behavior in The Six Party Talks}

The dynamics of North Korea's behavior is the evident of the Six Party Talks development which have been outlined above. North Korea shows a closed attitude, so many misunderstandings between North Korea with other countries involved in the Six Party Talks, in particular South Korea, the United States and Japan. North Korea showed more cooperative behavior when in dialogue with countries of similar ideologies such as China and Russia. Of these, two ideologies seen interacting in the Six Party Talks. First, the liberal ideology promoted by South Korea, Japan and the United States. Second, the communist ideology which is owned by North Korea, China and Russia. Then the effort conversation Six Party Talks is reasonably reflectedthe cornerstone of the two ideologies are struggling, namely the South Korea and North Korea.

Most of the behavior exhibited by North Korea in the development of the Six Party Talks is a threat. North Korea several times threatened to proceed its nuclear weapons development program. NorthKorea hold comprehensive threats as a form of thedeterrence of use of force (prevention). North Korea prevention of other countries to harm or attack North Korea, the threat of a nuclear program. Although using nuclear weapons as a threat, North Korea's actioneffort is a peaceful defensive. Politicalstrategy uses of force in the form of deterrenceby denialis used by North Korea; revealing the power that the country is still conducting nuclear development program. North Korea's actions included in the action deterrenceby denial since North Korea prevention efforts in the form of threats by revealing the power to its opponent. North Korea revealed that the country is developing nuclear and uranium enrichment. Other actions that show the action of deterrencedenial by North Korea is missiles launch and nuclear test. North Korea again wants to show military strength is being owned and developed as a threat and prevention to the attack of other countries.

North Korea's defensiveeffort is not only able to prevent attacks from another country, but also have an impact on the appearance of a security dilemma. Other countries did not attack North Korea, but it also resulted in the emersion of the security dilemma. Security dilemma arises when a country shows its strength. The appointment of the strength of a country will make other countries threatened, and so will try to increase the country's military strength. Then the state or others who see the efforts to increase the country's military strength will also feel threatened, and sought again to upgrade its military strength. The situation will continue to occur with the same cycle.

Dilemmas security appears in the middle of the country at odds with North Korea, which South Korea. Tensions conflict not ended, and the location is very close to North Korea making South Korea act aggressively upgrading or improvement of its military power. As security threats in the form of nuclear weapons cultivation program of North Korea, the South Korean military forces got busy. This is evident from the efforts of a joint military action held by South Korea along with the United States in the border region which are done several times. South Korea feels endangered by the news and discourse project of North Korea's nuclear weapons development and continued to work on improving military capabilities with the support of the United States. 
In diplomacy and communication, visible difference in the two camps with different ideologies in the Six Party Talks. South Korea also looks tighten cooperation with Japan and the UnitedStates. The three countries even issued a trilateral agreement that called on North Korea to stop developing nuclear. Meanwhile, the North Korean side, the state of China and Russia to lead a liaison diplomacy. When North Korea was about to get out of the Six Party Talks, the Chinese and the Russians are always trying to reassure North Korea to end up going back to join the forum.

\section{Conclusion}

Tension and conflict on the Korean peninsula, which lasted from 1950 have not seen the point of peace until now. Various attempts to reconcile the North and South Korea continue to do, but have not produced results. Current effort is the establishment of the Six Party Talks or Talks Six Nations, which was initiated in 2003. Six Party Talks was initiated by China, managed to maintain the United States, Japan, Russia, North Korea, and South Korea to sit together to ease tensions on the Korean peninsula. Six Party talks was also initiated as a forum for negotiation and communication to North Korea, particularly with respect to its nuclear development program.

Unfortunately, the peace forum Six Party Talks haven't give any significant influence to the reconsiliation in Korean Peninsula; but the Six Party Talks contribute to the status quo of the conflict between North Korea and South Korea. The dynamics relations among North Korea and other countries in the negotiations is still not stable. It is also because of diplomatic relations is not running smoothly. If the other party is not willing to agree to his request, then North Korea showed behavior that most tend defensive passing threat. Preventive action (deterrenceuse of forceby denial) repeatedly carried out by North Korea to threaten other countries and unlock the power of its nuclear development program.

North Korea's behavior was influential to other parties who are in conflict with these countries, namely South Korea. South Korea, which feel threatened security as viewed North Korea's nuclear development and then conduct joint military exercises the United States in the border area. This is done in South Korea as well as defensive effort to open the preparation of military force which was built along the US side. Each of these countries feel threatened by efforts to improve the military another party, and then try to increase military forces for the security of their respective countries. This shows the security dilemma that struck North Korea and South Korea, as the effects of defensive behavior exhibited by North Korea. In fact, it can be concluded that the defensive behavior of North Korea and South Korea are already so entrenched that now appears very naturally.

\section{References}

[1]D. Oberdorfer, The Two Koreas a Contemporary History, Revise and Update. United States of America: Basic Books, 2001.

[2]I. C. Group, "North Korea : Beyond the Six-Party Talks," Asia Rep., vol. 269, no. June, 2015.

[3]"Six-Party Talks," Inventory of International Nonproliferation Organizations and Regimes Center for Nonproliferation Studies. .

[4]R. Jervis, "Cooperation Under the Security Dilemma," World Polit., vol. 30, no. 2, pp. 
$167-214,1978$.

[5]R. J. Art, "The Political Use of Force," in International Politics Enduring Concepts and Contemporary Issues, R. J. Art and R. Jervis, Eds. United States of America: Pearson Longman, 2009, pp. 127-138.

[6]C.-I. Moon, "The North Korean Nuclear Dilemma and the Six-Party Talks: A South Korean Perspective," no. September 2005, 2007.

[7]S. Muhammad, "Masalah Nuklir Dalam Hubungan Korea Utara-Amerika Serikat," in Konflik dan Perkembangan Kawasan Pasca Perang Dingin, P. Nainggolan, Ed. Jakarta: Pusat Pengkajian dan Pelayanan Informasi (P3I) Sekretariat Jenderal Dewan Perwakilan Rakyat Republik Indonesia., 2004, pp. 49-75.

[8]M. Martin, "The Six-Party Talks and New Opportunities to Strengthen Regional Nonproliferation and Disarmament," 2009.

[9]S. S. Kim, "China and the Six-Party Talks : The New Turn to Mediation Diplomacy," Int. J. Korean Stud., vol. IX, no. 2, 2005.

[10]Y. Fu, "The Korean Nuclear Issue: Past, Present, and Future,” Brookings Inst., no. May, 2017.

[11]M. Lee, “The EU and the Six-Party Talks,” Inst. Aff. Internazionali, vol. 17, 2017. 